Nippon Suisan Gakkaishi $\quad$ 71(4), 542-548 (2005)

\title{
曳航式深海用ビデオカメラで撮影した ベニズワイガニの甲幅推定法
}

高 橋 秀行, ${ }^{*}$ 渡部 俊 広, ${ }^{1}$ 北川大 二 $^{2}$

（2004 年 1 月 5 日受付, 2004 年 11 月 15 日受理）

19独水産総合研究センター水産工学研究所, 2多蟋水産総合研究センター西海区水産研究所

A method to estimate carapace width of the red queen crab Chionoecetes japonicus using video images taken with a deep-sea video monitoring system on a towed sledge

Hideyuki TAKAHASHI, ${ }^{*}$ TOSHIHIRo WATANABE ${ }^{1}$ AND DAIJI KITAGAWA²

${ }^{1}$ National Research Institute of Fisheries Engineering, Fisheries Research Agency, Hasaki, Ibaraki 314-0421, ${ }^{2}$ Seikai National Fisheries Research Institute, Fisheries Research Agency, Nagasaki, Nagasaki 851-2213, Japan

Carapace widths of the red queen crab Chionoecetes japonicus were estimated using the video images taken with a deep-sea video monitoring system on a towed sledge (DVMSTS). A formula to convert the position on the video image to the real scale on the sea floor has been developed. The conversion was calibrated based on video images of a perspective grid recorded by DVMSTS in an experimental tank. In the in situ observation, the points of interest (left and right edges of a carapace) are above the sea floor and this causes an estimation error. By correcting the error, we obtained an accurate estimation of carapace width. The error ranged within $\pm 10 \mathrm{~mm}$ when the sample was approximately within $500 \mathrm{~mm}$ from the sledge of DVMSTS.

キーワード : 曳航式深海用ビデオカメラ, 画像計測, 甲幅, ベニズワイガニ

日本海における重要な水産資源であるべニズワイガニ Chionoecetes japonicus は, 主に籠漁具で漁獲され, 1980 年代には約 53,000 トンの漁獲があった。しかし, その後の漁獲量は急激に減少し続け, 資源状態の悪化が 懸念されている。1)このため, 現存量推定に基づいて資 源を管理し，持続的利用を図る必要がある。2,3) しかし， 日本海のベニズワイガニは水深 $500 \sim 2700 \mathrm{~m}$ の海底に 広く分布するため, 4-7) 現在資源量を推定するための有 効な手法がない。このため, ベニズワイガニの資源状態 は, 漁獲量と漁獲成績報告書（漁業者は, 大臣または知 事から漁業の許可を受ける際に, 揚籠年月日, 操業漁 区，使用した籠数，漁獲重量等の報告を義務付けられ る）から推定した 1 籠あたりの漁獲重量の経年変化に 基づいて, その水準を判断している。8 漁獲が許可され ている甲幅 $90 \mathrm{~mm}$ を超える雄の現存量は, 漁獲量, 漁 獲努力量（有効漁獲強度）と漁具能率あるいは有効漁獲 面積 (生息密度に対する 1 籠あたりの漁獲個体数 ${ }^{9}$ か ら推定が可能である。10)このうち, 漁獲量と漁獲努力量
は，漁業成績報告書から推定できる。生息密度は，曳航 式深海用ビデオカメラ11-16)によって推定できる。した がって, 曳航式深海用ビデオカメラで撮影したベニズワ イガニの甲幅を推定できれば, 甲幅 $90 \mathrm{~mm}$ を超える雄 に対する籠漁具の有効漁獲面積がわかり, 漁獲可能な個 体の現存量推定が可能となる。9,10)

ズワイガニ類の生息密度を推定するために開発した曳 航式深海用ビデオカメラ11-16) には, 1 台の水中ビデオカ メラが搭載されている。1台の水中カメラで撮影した画 像から海底面上の物体の位置や大きさを推定する方法々 して, perspective grid (Canadian grid とも言われ, 平 面上に直線が格子状に描かれてある。以下, グリッド平 面と呼ぶ）が用いられてきた。9,17-28)この方法では, 水 中カメラで水槽の底面に描かれたグリッド平面を撮影し た画像を, 実際の調査で海底面を撮影した画像に重ね合 わせることによって, 海底面上の物体の位置や大きさを 推定する。一方, Wakefield and Genin ${ }^{22}$ は, グリッド 平面を撮影しなくても, 水中カメラの画角と海底面に対

* Tel : 81-479-44-5945. Fax : 81-479-44-1875. Email : hideyuki@fra.affrc.go.jp 
する水中カメラの位置から, 海底面上の物体の位置や大 きさを推定できる perspective grid method（以下，グ

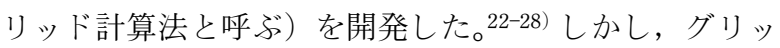
ド計算法では, 多種多様にある撮影用光学機器の光学系 を全て正確に記述できるかどうか検証されていない。ま た,グリッド計算法を適用したほとんどの研究は, 推定 精度について言及していない。24-28) したがって, 画像か ら物体の位置や大きさを推定するには, グリッド平面を 用いる方法が実用的である。

本研究では, 曳航式深海用ビデオカメラによって撮影 した画像から, グリッド平面を利用して, ベニズワイガ 二の甲幅推定法について検討した。ベニズワイガニには 甲殼の厚みや歩脚があり, 甲幅を推定する際の計測点は 海底面から離れている。このため, 単にグリッド平面を 適用するだけでは䛊差が生じるので，この䛊差を補正し て甲幅の推定精度を高めた。また，実海域に扔いて曳航 式深海用ビデオカメラで海底面を観察した後に, 調査用 トロール網による操業を行い, カメラで推定したベニズ ワイガニの甲幅組成と調查用トロール網で漁獲したベニ ズワイガニの甲幅組成を比較して, 画像による甲幅推定 法の妥当性を検討した。

\section{方法}

曳航式深海用ビデオカメラ 曳航式深海用ビデオカメ ラ11-16) は，主にズワイガニ類の生息密度を推定するた めに開発され，そり型の曳航台に水中ビデオカメラと水 中ライトが搭載されている。水中ビデオカメラは曳航台 の後部中央の上側に前方斜め下向きに固定され, 曳航台 前方の海底面と曳航台前端部を俯瞰する。

計測環境 曳航式深海用ビデオカメラで撮影した画像 を解析するため, コンピュータに画像をビットマップ形 式（横 $640 \times$ 縦 480 ドット）で取り込んだ。画像処理ソ フトウェア (Adobe Photoshop) を用いて画像の座標値 を読み取り, 表計算ソフトウェア (Microsoft Excel) を用いて甲幅を推定するための計算式を求めた。

甲幅の推定方法 画像の座標值から甲幅を推定するに あたり, 海底面は平坦であり, 曳航式深海用ビデオカメ ラの曳航台は海底面に接地した状態で安定して曳航され ると仮定した。画像面の座標系 $(x, y)$ は, 画像面の左 上端を原点, 水平方向を $\mathrm{X}$ 軸 (右側が正方向), 垂直方 向を $\mathrm{Y}$ 軸（下側が正方向）とした（Fig. 1)。海底面の 座標系 $(X, Y)$ は, 曳航台の接地面前端の中間点を原 点, 曳航式深海用ビデオカメラの曳航方向に直交する方 向を X 軸 (右側が正方向), 曳航方向を $\mathrm{Y}$ 軸 (曳航方 向が正方向）とした。海底面の $\mathrm{X}$ 軸方向の原点は画像 面の中心 $(x=319$ dots $)$ とし, $\mathrm{Y}$ 軸方向の原点は曳航 台が海底に接地する面の前端の座標を，グリッド平面 (詳細は後述) を撮影した画像から求めた。

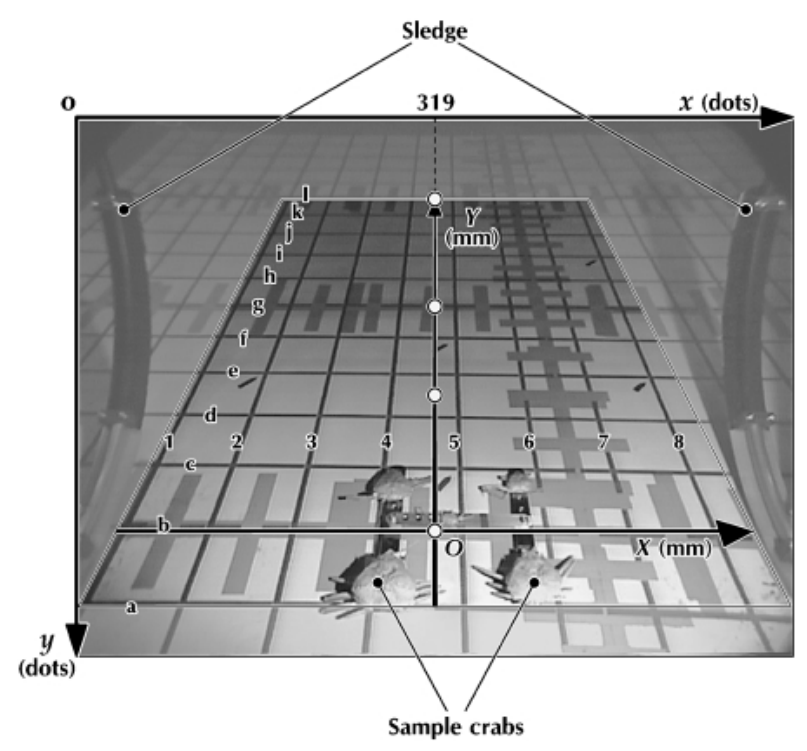

Fig. 1 Schematic of correspondence between coordinate systems of video image (small letter) and that of seafloor (capital letter) overlaid on the video image of the perspective grid photographed by DVMSTS. Circles are approximate positions where samples of the red queen crab Chionoecetes japonicus were placed. Each grid line is labeled for explanation.

海底面に打ける $\mathrm{Y}$ 軸方向の位置 $Y(\mathrm{~mm})$ は, 曳航台 から離れるほど画像の上端側になる。したがって は, 画像面に抢ける Y 軸方向の位置 $y$ (dots) の関数と して表すことができる。

$$
Y=F_{1}(y)
$$

一方, 海底面に抢ける $\mathrm{X}$ 軸方向の位置 $X(\mathrm{~mm})$ は, 画像面の左端から右端に向けて大きくなる。しかしその 度合いは曳航台からの距離によって变化する。すなわ ち, 海底面の $\mathrm{X}$ 軸方向の長さは, 曳航台から $\mathrm{Y}$ 軸方向 に離れるほど, 画像上では小さくなる。したがって, X 軸方向に抢ける海底面の長さ $1 \mathrm{~mm}$ あたりのドット数 $W(\operatorname{dots} / \mathrm{mm})$ は, $y$ の関数として表すことができる。

$$
W=F_{2}(y)
$$

$\mathrm{X}$ 軸方向の原点は $x=319$ (dots) であるから, $x$ は次式 によって $X$ に変換できる。

$$
X=\frac{x-319}{W}
$$

したがって, 曳航式深海用ビデオカメラに適合する(1), (2)式を求めれば, 曳航式深海用ビデオカメラの画像面 の座標を海底面の座標に変換できる。

変換式を求めるため, 水産工学研究所・海洋工学総合 実験棟の水槽（以下, 試験水槽と呼ぶ）底面に大きさ $4000 \mathrm{~mm} \times 4000 \mathrm{~mm}$ ，格子の大きさ $200 \mathrm{~mm} \times 200 \mathrm{~mm}$ のグリッド平面を設置した。その上に曳航式深海用ビデ オカメラを設置してグリッド平面を撮影した（Fig. 1)。 
便宜上，Y 軸方向の線に $1,2,3, \cdots \cdots, \mathrm{X}$ 軸方向の線に $a$, $b, c, \cdots \cdots$ 記号を割り当てた。曳航式深海用ビデオカメ ラは, 曳航台の接地面の前端がグリッド平面上の線 $b$ と 一致するように設置した。各線の画像上の位置から(1), (2)式を近似式として求めた。得られた変換式から計測 対象の甲殼の左端・右端の位置を推定し， 2 点間の距離 を甲幅推定值 $S(\mathrm{~mm})$ として求めた。

測定誤差の補正 ベニズワイガニの甲殼には厚みがあ るため, 甲幅の計測点は海底面から離れる。このため, 画像上の計測点の座標を海底面上の座標に変換するだけ では誤差が生じる。䛊差の傾向を表す要素としては, 計 測対象物の大きさと, 曳航台からの距離が考えられる。 すなわち, 計測対象物が大きいほぼ, 計測点は海底面か ら離れ, 䛊差が大きくなる。また, 計測対象物が遠く離 れるほど, 水中ビデオカメラと計測対象物とを結ぶ直線 が海底面と成す仰角が小さくなり, 誤差が大きくなる。 したがって, 計測点が海底面から離れて生じる誤差 $E$ $(\mathrm{mm})$ は, 甲幅推定值 $S$ と曳航台からの距離の推定值 $D(\mathrm{~mm})$ の関数として表すことができる。試験水槽で 甲幅が既知の標本を撮影し, 実測值と推定值を比較し て, $S, D$ と $E$ の関係式,

$$
E=F_{3}(S, D)
$$

を求めた。 $S$ から $E$ の差を取り, 誤差を補正した甲幅 推定值 $S_{c}(\mathrm{~mm})$ を求めた。

標本として, 大きさの異なる 5 個体のベニズワイガ 二 (甲幅 : $131 \mathrm{~mm}, 115 \mathrm{~mm}, 96 \mathrm{~mm}, 67 \mathrm{~mm}, 41 \mathrm{~mm}$ ) を用いた。標本は $\mathrm{H}$ 字状の治具にテグスで固定し, 同 時に移動した。標本の固定位置は, 甲幅 $131 \mathrm{~mm}$ が左 下, $115 \mathrm{~mm}$ が右下, $96 \mathrm{~mm}$ が左上, $67 \mathrm{~mm}$ が右上, $41 \mathrm{~mm}$ が中央とした（Fig. 1)。標本は，曳航台の前端 からの距離約 0.0, 0.5, 1.0, $2.0 \mathrm{~m}$ に配置して撮影した。 撮影方向が推定精度に及ぼす影響を検討するため（詳細 は後述), 距離約 $0.5,1.0,2.0 \mathrm{~m}$ について, 曳航方向を 基準 (0 度) に時計回りに 45 度ずつ回転して撮影した。 距離約 $0.0 \mathrm{~m}$ については 0 度のみを撮影した。曳航台 からの距離の推定值は，5個体の平均值として扱った。 測定誤差の補正については, 甲幅推定值は各撮影方向で の推定値の平均值として扱った。

撮影方向と推定精度の関係 計測対象物が遠く離れる ほど, 水中ビデオカメラと計測対象物とを結ぶ直線が海 底面に対して成す仰角が小さくなる。そのため, 曳航式 深海用ビデオカメラに対するべニズワイガニの甲凯の方 向によっては, 計測点が死角になることがある。したが って, ベニズワイガニの方向は, 推定精度に影響を及ぼ す可能性がある。そこで, 測定誤差の補正で用いた画像 のうち, 標本の方向を 45 度ずつ回転して撮影した画像 （距離約 $0.5,1.0,2.0 \mathrm{~m}$ ）を用いて誤差を補正した甲幅 推定值を求め, 撮影方向と推定精度の関係を検討した。
実用性の検証 実海域で撮影した画像を用いてべニズ ワイガニの甲幅を推定した。曳航式深海用ビデオカメラ を用いて, 1999 年 5 月 21 日に福島県沖 $\left(37^{\circ} 30.86^{\prime} \mathrm{N}\right.$, $141^{\circ} 58.22^{\prime} \mathrm{E}$, 水深約 $500 \mathrm{~m}$ ) の海域で撮影した画像か ら甲幅を推定して, 甲幅組成を求めた。ほほほ同時期 （1999 年 6 月 6 日）に曳航式深海用ビデオカメラの曳航 ラインに沿って曳網した調查用トロール網の漁獲から得 た甲幅組成と比較した。

\section{結果}

甲幅の算出 線 $a$ の $y$ 座標の平均值は $y=435(\operatorname{dots})$ であったため, 海底面の原点を $\left(x_{0}, y_{0}\right)=(319,435)$ とした。

画像上に打ける線 $a \sim l$ の位置の平均值から, $y$ と $Y$ の関係を次式によって近似した。

$$
y=435 e^{-0.000794 Y} \quad\left(R^{2}=1.00\right)
$$

これを変換して，yを $Y$ に変換する式を得た。

$$
Y=-\frac{\log _{e} y-\log _{e} 435}{0.000794}
$$

次に, 線 $a \sim l$ 上に拈けるグリッド一目盛 $(200 \mathrm{~mm})$ あたりの長さの平均值（dots）から, X 軸方向 1 ドット あたりの海底面の長さ $W$ を求めた。そして, $W$ と $y$ の 関係を次式によって近似した。

$$
W=0.000656 y+0.136 \quad\left(R^{2}=1.00\right)
$$

(7)式を $(3)$ 式に代入し， $x$ を $X$ に変換する式を得た。

$$
X=\frac{x-319}{0.000656 y+0.136}
$$

(6), (8) 式により, 画像面の座標 $(x, y)$ を海底面の 座標 $(X, Y)$ に変換する式を得た。

試験水槽で甲幅が既知の標本を用いて撮影した画像か ら，(6)，(8)式を用いて計測点（甲殼の左右端）の位置 を推定した。距離約 $1.0 \mathrm{~m}$ に打ける撮影方向 225 度の 画像が久落したため, 該当部分は空白とした。また, 距 離約 $2.0 \mathrm{~m}$ の画像に抢いては, 甲幅 $41 \mathrm{~mm}, 67 \mathrm{~mm}$ の 一部 $(0,45,90,270,315$ 度), 抢よび $96 \mathrm{~mm}$ の一部 (0, 45, 90, 315 度) で輪郭が明瞭に視認できなかったた め, 推定に用いなかった。左右の計測点間の距離を甲幅 推定值 $S$ として求好実測值と比較し, 個体毎に測定 誤差と推定距離の関係を示した (Fig. 2)。曳航台から 約 $0.0,0.5,1.0,2.0 \mathrm{~m}$ 前方に配置して撮影した標本の推 定距離は, それぞれ 111, 401, 1026, $2146 \mathrm{~mm}$ であっ た。甲幅推定值は, 小型個体 (甲幅 $41,67 \mathrm{~mm}$ ) では実 測值より小さく, 大型個体 (甲幅 $96,115,131 \mathrm{~mm}$ ) で は大きかった。特に大型個体では, 水中ビデオカメラか ら離れるほど大きく推定された。

測定誤差の補正 甲幅推定值 $S$ と測定䛊差 $E$ の関係 を, 推定距離別に Fig. 3 に示した。全ての推定距離 で, 測定誤差が最小になる点は甲幅推定值 $80 \mathrm{~mm}$ 付近 


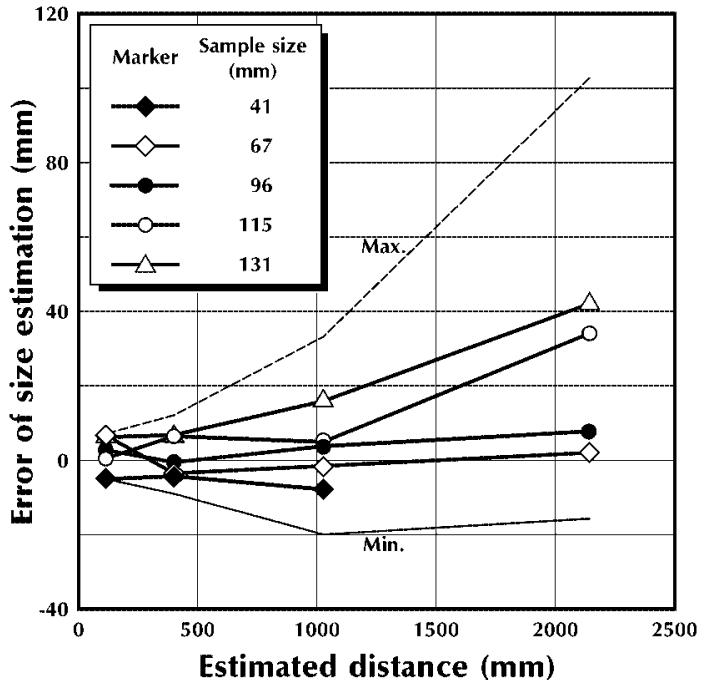

Fig. 2 Error of size estimation (correction term is not included). Actual carapace width of each sample crab is in the legend.

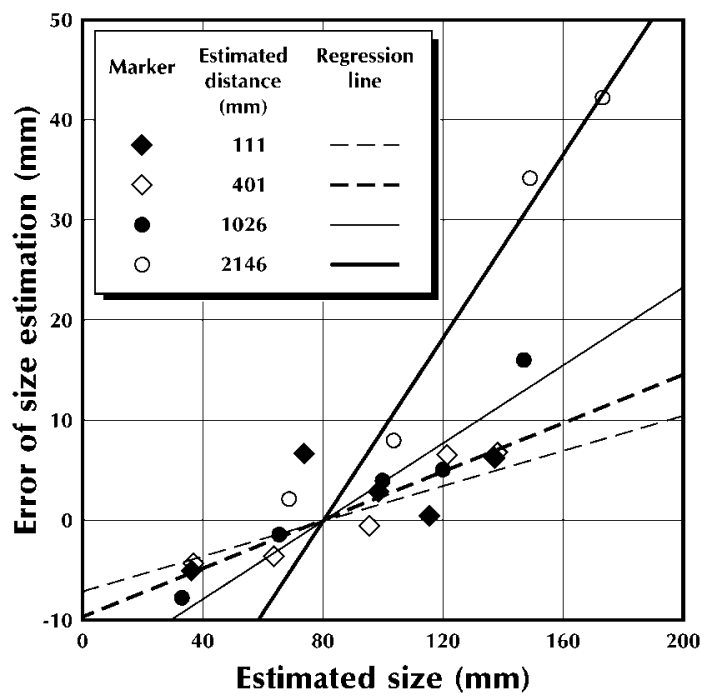

Fig. 3 Linear relationship between estimated size and error at each distance from the sledge. Each regression equation is in the text.

にあり，それより小さいと過小に，大きいと過大に推定 する傾向があった。そこで，SとEの関係を，(80，0) を通過する一次式で近似した。各推定距離における測定 誤差 $E_{D}(\mathrm{~mm})$ の近似式は次のようになった。

$$
\begin{array}{ll}
E_{111}=0.0875(S-80) & \left(R^{2}=0.31\right) \\
E_{401}=0.121(S-80) & \left(R^{2}=0.90\right) \\
E_{1026}=0.195(S-80) & \left(R^{2}=0.94\right) \\
E_{2146}=0.456(S-80) & \left(R^{2}=0.94\right)
\end{array}
$$

(9)〜 (12)式の勾配は, 推定距離が離れるにしたがって 増加する傾向にあった。そこで, 推定距離 $D$ と勾配 $G$

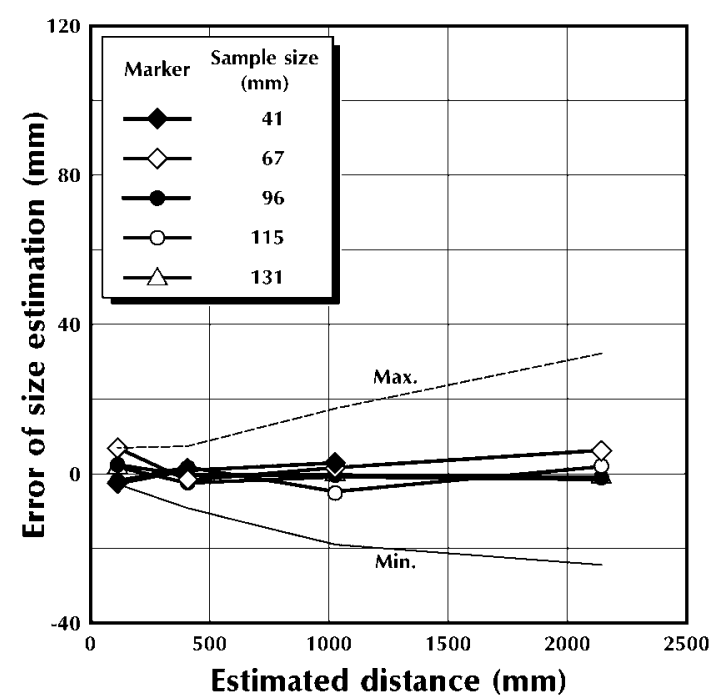

Fig. 4 Error of size estimation (correction term is included). Actual carapace width of each sample crab is in the legend.

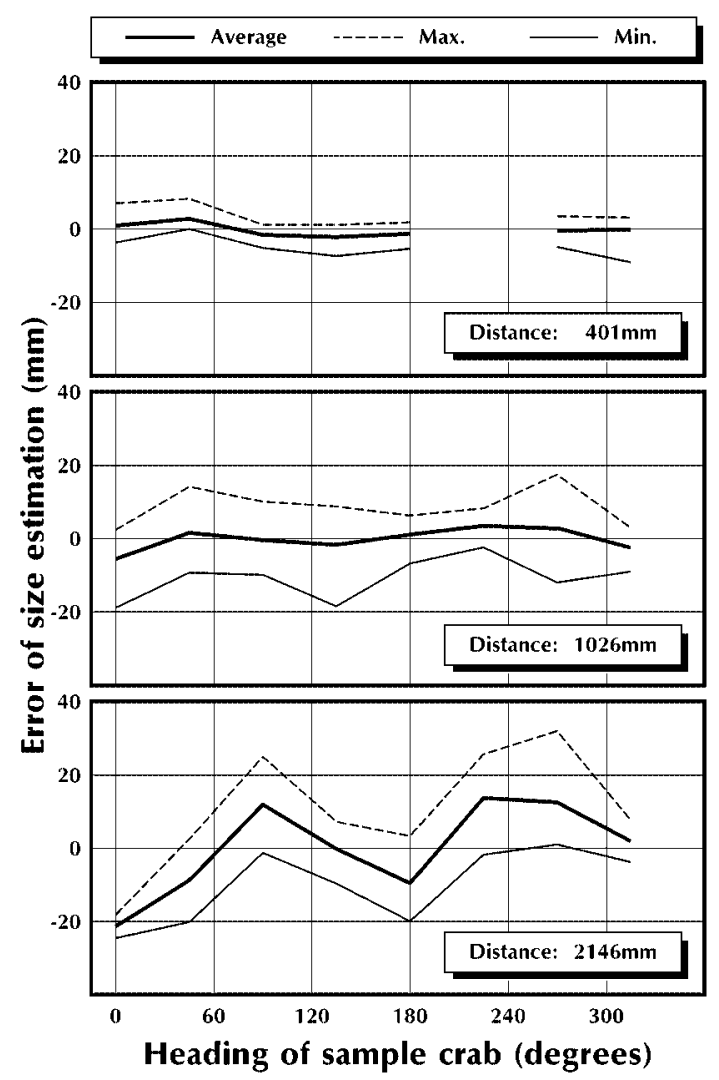

Fig. 5 Relationship between error of size estimation and heading angle of sample crabs.

の関係を次式によって近似した。

$$
G=0.000183 D+0.0465 \quad\left(R^{2}=0.97\right)
$$



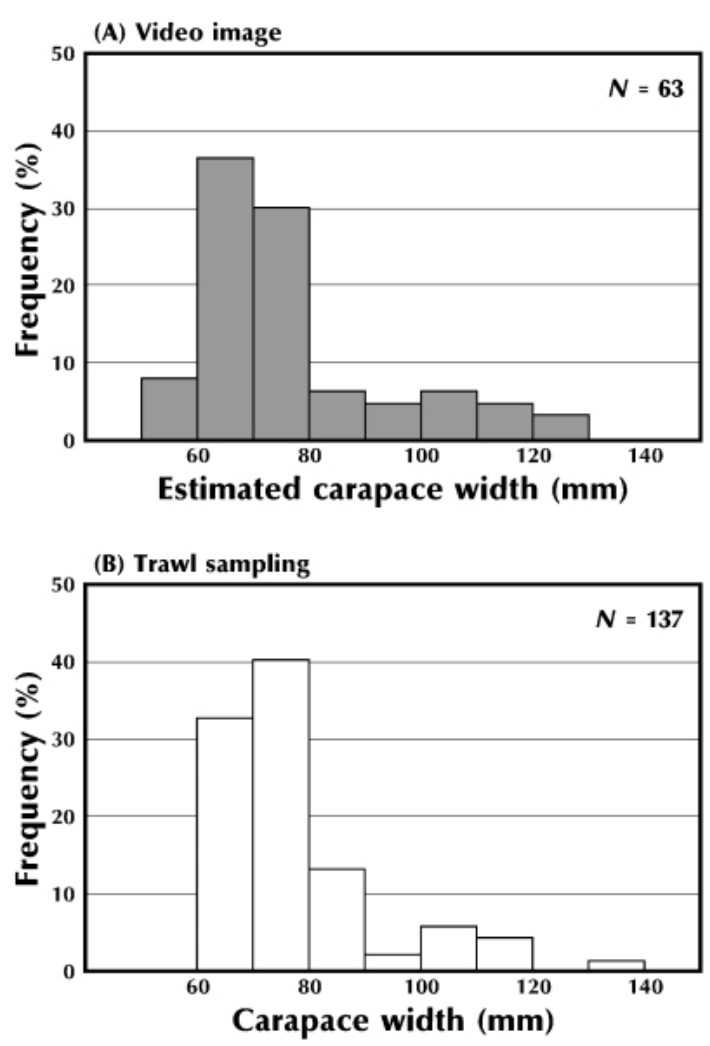

Fig. 6 Size frequency distributions based on (A) size estimated from DVMSTS video images, and (B) size of trawl samples.

$$
\begin{aligned}
E & =G(S-80) \\
& =(0.000183 D+0.0465)(S-80)
\end{aligned}
$$

$S$ から $E$ の差を取り, 誤差を補正した甲幅推定值 $S_{c}$ を求めた。補正後の甲幅推定值と実測值とを比較したと ころ, 推定距離 $111 \mathrm{~mm}, 401 \mathrm{~mm}$ においては, 誤差は 最大でも $10 \mathrm{~mm}$ 以内に収まった (Fig. 4)。推定距離 $2146 \mathrm{~mm}$ においては, 補正前では最大 $100 \mathrm{~mm}$ 以上に 達した測定誤差が， $30 \mathrm{~mm}$ 程度まで減少した。

撮影方向と推定精度の関係 Fig. 5 に, 標本の撮影方 向と測定誤差との関係を, 推定距離毎に示した。推定距 離 $401 \mathrm{~mm}$ では，撮影方向による測定誤差の変化はほ とんどなかった。一方, 推定距離 $2146 \mathrm{~mm}$ では, 撮影 方向が 0 度または 180 度のときに過小に，90 度または 270 度のときに過大に甲幅を推定する傾向があった。

実用性の検証 曳航式深海用ビデオカメラの画像から 推定した甲幅組成と, 調査用卜ロール網の漁獲から求め た甲幅組成を Fig. 6 に示す。画像解析では 63 尾, 調査 用トロール網では 137 尾を計測した。曳航式深海用ビ デオカメラの画像から推定した甲幅の範囲は $50 \sim 130$ $\mathrm{mm}$ で, モードは $60 \sim 70 \mathrm{~mm}$ にあった。一方, 調査用 トロール網の漁獲から求めた甲幅の範囲は 60〜 $140 \mathrm{~mm}$ で，モードは 70〜80 $\mathrm{mm}$ にあった。しかし, 甲幅組成
に有意な差はなかった（Kolmogorov-Smirnov test, $p<$ $0.10)$ 。

\section{考察}

グリッド平面を利用した手法や類似の手法を用いて， 海底面上の生物の分布や大きさを推定した研究17-28) は 多く行われているにもかかわらず，推定精度を言及した 例は少ない。22,23)これは, 計測点が海底面に接している ときは，原理的に測定誤差が生じないためと考える。し かしながら，ベニズワイガニには甲殼の厚みや歩脚があ るために, 計測点は海底面から離れているので, このこ とによって生じる測定誤差について検討し, 画像から求 めた甲幅の推定精度を高めた。

本研究で用いた標本は，5個体を治具に固定して同時 に設置した。このため, 実際の設置距離は個体毎に僅か なずれがある。しかし,ずれは最大でも $20 \mathrm{~cm}$ 程度で 測定誤差に与える影響は少ないので，5個体の推定距離 の平均值を用いた。補正前の測定誤差は, 甲幅 $80 \mathrm{~mm}$ 付近で最小になり，それより大型の個体では実際の甲幅 より大きく, 小型の個体では小さくなった。画像解析で は, 計測対象物の輪郭が不明瞭だと, 実際の輪郭より計 測者は内側を計測点として選択し，大きさを過小推定す ることが報告されている。29) 一方, 大型個体ほど計測点 が海底面から離れるので, 甲幅推定值は実際より大きく なる。しがたって，小型個体は前者の影響を強く受けて 過小に, 大型個体は後者の影響を強く受けて過大に推定 され，2つの誤差要因が甲幅推定值 $80 \mathrm{~mm}$ 付近で相殺 されたと考える。甲幅は, 曳航方向に対して標本の方向 が垂直になると過大に推定され，この傾向は計測対象物 と水中カメラとの距離が遠くなると顕著になった。これ は，観察時の仰角が小さくなるために甲殼の輪郭が不明 瞭になるためである。ズワイガニ類は, 曳航台の接近に 対してほとんど逃避行動を示さない11,12)ため，この問題 はズワイガニ類を最も計測しやすい画像を用いることで 解決できる。測定誤差 $\pm 10 \mathrm{~mm}$ 以内の推定精度を得る には, 推定距離 $500 \mathrm{~mm}$ を目安に, それより接近した ときの画像を用いれば良い（Fig. 4)。この範囲は, 画 像上では $y=292$ (dots) より下方の領域に相当する。

次に, 甲幅計測法の実用性について述べる。実海域に おいて曳航式深海用ビデオカメラで撮影した画像から推 定した甲幅組成と, 調査用トロール網の漁獲から求めた 甲幅組成との間には有意な差はなかった。しかし, 画像 から推定した甲幅組成のモードは，調査用トロール網の 漁獲から求めた甲幅組成のモードより小さかった。ま た, 水中ビデオカメラでは甲幅 $60 \mathrm{~mm}$ 以下の個体が観 察されたにも関わらず, 調査用トロール網では漁獲され なかった。これらは, 調査用トロール網のサイズ選択性 のために, 小型個体が漁獲されなかったためと考え 
る。 ${ }^{30)}$ したがって, 曳航式深海用ビデオカメラの曳航台 は, 海底面に接地した状態で安定して曳航されていたと 考えられ, 本計測手法の実用性が確認された。本研究で 求めた計算式は, ベニズワイガニに形態が近似している ズワイガニ31,32)の甲幅の推定にも適用できる。

海底面と一定の位置関係を保ちながら海底を俯瞰する 撮影装置であれば, 本研究と同様の方法で, 画像から海 底面上の位置を推定することができる。ただし，本計測 手法は, 広角レンズの使用等によって生じる画像の歪曲 を考慮していないので，画像の歪曲が大きい場合は推定 精度を向上するために画像補正を行い, 歪曲を極力除去 することが望ましい。計測点が海底面から離れている場 合も，ベニズワイガニのように常に海底面に接している 計測対象物であれば, その特性に応じた補正を行うこと で, 推定精度を向上できる。

\section{謝辞}

本研究にご協力戴いた漁業調査船第三開洋丸故小嶋洋 船長はじめ乗組員各位, ならびに東北区水産研究所漁業 調查船若鷹丸佐々木洋治船長はじめ乗組員各位に厚く御 礼申し上げる。また, 水産総合研究センター研究推進部 ならびに水産庁増殖推進部漁場資源課の関係各位に感謝 の意を表する。本研究は, 水産庁の我が国周辺漁業資源 調査等推進対策委託事業の一環として行った。

\section{文献}

1）渡部俊広，山㠃慎太郎. ベニズワイガニ籠漁業における 漁具の浸漬時間と漁獲. 日水誌 1999; 65: 642-649.

2) Yosho I. Reproductive cycle and fecundity of Chionoecetes japonicus (Brachyura: Majidae) off the coast of Central Honshu, Sea of Japan. Fish. Sci. 2000; 66: 940-946.

3) 吉原友吉, 久保伊津男. 「水産資源学改訂版」共立出版, 東京. $1969 ;$ p. 213.

4) Fujikura K, Tsuchida S, Hashimoto J. Density estimate of the beni-zuwai crab Chionoecetes japonicus, by an in situ observation method. Fish. Sci. 2000; 66: 1183-1185.

5）桑原昭彦.「日本海西部海域におけるズワイガニの資源管 理 (水産研究業書 44)」, 日本水産資源保護協会, 東京. 1995; 2-51.

6）富山県水産試験場, 島根県水産試験場, 鳥取県水産試験 場.「ベニズワイガニの資源と生態に関する研究報告書」 1988; 1-98.

7) Yosho I, Hayashi I. The bathymetric distribution of Chionoecetes opilio and C. japonicus (Majidae; Brachyura) in the western and northern areas of the Sea of Japan. Bull. Japan Sea Natl. Fish. Res. Inst. 1994; 44: 59-71.

8）水産庁.「我が国周辺水域の漁業資源評価」水産庁, 東京. 2002; 304-310.

9) Miller RJ. Density of the commercial spider crab, Chionoecetes opilio, and calibration of effective area fished per trap using bottom photography. J. Fish. Res. Board Can. 1975; 32: 761-768.

10）渡部俊広, 前田経雄, 養松郁子, 白井 滋. 曳航式深海 用ビデオカメラを用いたベニズワイガニに対する籠漁具 の有効漁獲面積推定に関する予備試験。水工研技報
2004; 26: 17-22.

11）渡部俊広, 山㠃慎太郎. 曳航式深海用ビデオカメラによ るべニズワイガニの分布観察. 日水誌 1999; 65: 503504.

12）渡部俊広, 廣瀬太郎. 曳航式深海用ビデオカメラによる ズワイガニの生息密度の推定. 日水誌 $2001 ; 67: 640-$ 646.

13) Watanabe T. Method to estimate the population density of the snow crab Chionoecetes opilio using a deep-sea video monitoring system on a towed sledge. Japan Agr. Res. Quarterly 2002; 36: 51-57.

14）渡部俊広, 渡辺一俊, 北川大二. 曳航式深海用ビデオカ メラを用いたキチジの生息密度推定法. 日水誌 2003 ; 69: 620-623.

15）渡部俊広. 曳航式深海用ビデオカメラを用いたズワイガ 二類の生息密度推定法と調査用トロール網の採集効率の 推定. 海洋水産エンジニアリング 2004; 31: 71-76.

16）渡部俊広, 北川大二. 曳航式深海用ビデオカメラを用い たズワイガニ類に対する調査用トロール網の採集効率の 推定. 日水誌 2004; 70: 297-303.

17) Grazzle JF, Sanders HL, Hessler RR, Rowe GT, McLellan T. Pattern and zonation: a study of the bathyal megafauna using the research submersible Alvin. Deepsea. Res. 1975; 22: 457-462.

18) Uzmann JR, Cooper RB, Theroux RB, Wigley RL. Synoptic comparison of three sampling techniques for estimating abundance and distribution of selected megafauna: submersible vs camera sled vs otter trawl. Mar. Fish. Rev. 1977; 39: 11-19.

19) Rice AL, Aldred RG, Billet DSM, Thurston MH. The combined use of an epibenthic sledge and a deep-sea camera to give quantitative relevance to macro-benthos samples. Ambio Spec. Rep. 1979; 6: 59-72.

20) Smith CR, Hamilton SC. Epibenthic megafauna of a bathyal basin off southern California: patterns of abundance, biomass, and dispersion. Deep-sea. Res. 1983; 30: 907-928.

21) Smith CR. Food for the deep sea: utilization, dispersal, and flux of nekton falls at the Santa Catalina Basin floor. Deep-sea. Res. 1985; 32: 417-442.

22) Wakefield WW, Genin A. The use of Canadian (perspective) grid in deep-sea photography. Deep-sea. Res. 1987; 34: 469-478.

23) Kaufmann RS, Wakefield WW, Genin A. Distribution of epibenthic megafauna and lebensspuren on two central North Pacific seamounts. Deep-sea. Res. 1989; 36: 18631896.

24) Smith KLJ, Kaufmann RS, Wakefield WW. Mobile megafaunal activity monitored with a time-lapse camera in the abyssal North Pacific. Deep-sea. Res. I 1993; 40: 2307-2324.

25) Smith KLJ, Kaufmann RS, Baldwin RJ. Coupling of nearbottom pelagic and benthic processes at abyssal depths in the eastern North Pacific Ocean. Limnol. Oceangr. 1994; 39: 1101-1118.

26) Lauerman LM, Kaufmann RS, Smith KLJ. Distribution and abundance of epibenthic megafauna at a long time-series station in the abyssal northeast Pacific. Deep-sea. Res. I 1996; 43: 1075-1103.

27) Kaufmann RS, Smith KLJ. Activity patterns of mobile epibenthic megafauna at an abyssal site in the eastern North Pacific: results from a 17-month time-lapse photographic study. Deep-sea. Res. I 1997; 44: 559-579. 
28) Cranmer TL, Ruhl HA, Baldwin RJ, Kaufmann RS. Spatial and temporal variation in the abundance, distribution and population structure of epibenthic megafauna in Port Foster, Deception Island. Deep-sea. Res. II 2003; 50: 18211842.

29) Harvey E, Fletcher D, Shortis M. A comparison of the precision and accuracy of estimates of reef-fish lengths determined visually by divers with estimates produced by a stereo-video system. Fish. Bull. 2001; 99: 63-71.

30) Somerton DA, Otto RS. Net efficiency of a survey trawl for snow crab, Chionoecetes opilio, and tanner crab, C. bairdi. Fish. Bull. 1999; 97: 617-625.

31）山本孝治. 但馬沖合から採集したベニズワイ（新称）に 就いて. 日水誌 1950; 15: 519-523.

32) 深滝 弘. ベニズワイガニとズワイガニの雌の外部形態 の比較. 日水研報告 $1950 ; 15: 1-11$. 